\title{
WOMEN FOR GLOBAL GROWTH: NEED FOR WOMEN ECONOMIC EMPOWERMENT
}

\section{EKA SEPASHVILI}

Doctor of Economics

Associate Professor

Ivane Javakhishvili Tbilisi State University, Georgia

Eka.sepashvili@gmail.com

KEYWORDS: GENDER EQUALITY, WOMEN ECONOMIC EMPOWERMENT, GLOBAL GROWTH.

For citation: Sepashvili E. (2019), Women For Global Growth: Need For Women Economic Empowerment, Globalization And Business, №7, pp. 96-103. https://doi.org/10.35945/gb.2019.07.012

\begin{abstract}
"Policy-makers need to take concrete action to help women achieve equal access to opportunities - to education, to productive resources, and to full equality under the law" Christine Lagarde, Managing Director, IMF.
\end{abstract}

\section{INTRODUCTION}

Modern economic development heavily relies on new technologies and unprecedented development of science creating more and more new innovative products and services. The forth industrial revolution fundamentally differs from the previous ones. The new inventions connect digital technologies to almost every product and service and impact the development of all spheres: economic, political, social, cultural, environmental and etc. Modern knowledge-based global economy rises new goals for policy-makers wishing and trying to increase welfare of the country in a way to benefit all citizens of a national state. In such reality the demand for knowledge generation and improvement of resource efficiency is critical.

The equal impact and contribution of women and men in this process of modern transformation, deep economic changes and societal alteration is critical as global economy continuously moves towards the new fifth industrial revolution, where knowledge and cognitive skill have the imperative. More than ever, nations cannot afford to lose the skills, ideas and perspectives of women who are currently under-represented - in order to utilize the promise of a more prosperous and human-centric future that is to be come soon by contemporary innovations and technologies.

New challenges for national economic policies generate new approaches which have to face these modern developments and trends. One of the efficient practices represents women promotion for a very simple reason: women yet are not fully engaged into development and their economic potential has to be unlocked to benefit not only economic goals but also social inclusion and human development to meet upmost goal of every state: inclusive growth and high level of welfare. In this regard, the women promotion and their empowerment are key policy challenges. Nowadays the need for women advancement in all spheres of the society is clear and generates no doubts for reasonability and rationality of such approach to economic growth.

Generally speaking, all types of inequality have economic prerequisite, circumstances and consequences. Therefore, in this paper we mostly focus on the economic side of the discrimination and lack of gender balance between men and women in economic terms. Despite the significant progress mankind has reached in the past 20 century, women still are not equal partners with men in the economy, politics and society: the gap between them remains large. Gender balance in economic, which means equal presentation at economic decision-making, merit-based participation in the labour force, presence in managerial and leadership positions, access to resources and etc., is not inevitably ideal for every nation, society or individual. But creating equal opportunities for both gender and then giving them possibility to choose relying on their own preferences is the key for any state to achieve 
and guarantee higher level of welfare. At the same time, we should not miss the sectors where men are disadvantaged relative to women. Thus, when we speak about transformation and creating incentives for women promotion, we should be conscious not to exaggerate and keep focus on improving parity between men and women.

\section{LITERATURE REVIEW}

The importance of gender balance in economic performance is growing due to the effects of globalization, which deepens the gap between men and women, in terms of access to political-economic power and resources. As Schwab (2017) notes, deepening the globalization may result grave consequences: organizations might be unable to adapt with new environment; governments could fail to employ and regulate new technologies to capture their benefits; inequality may grow and societies' fragmentation continues. As human capital is the key to technology, knowledge and innovations, its gender dimension does matter. Hence, national economies have to devote a great deal of attention to human resource efficiency. Therefore, governments should create appropriate conditions and/or incentives for business actors to focus on innovative products and services (Sepashvili 2018b). In this regard, gender equality represents a key factor for unlocking the economic potential of nation states and for leveraging economic growth (Sepashvili 2019).

Societies with greater gender equality not only offer better socio-economic opportunities for women, but also tend to grow faster and more equitably. There are gains in poverty reduction, environmental sustainability, consumer choice, innovation and decision-making on a wider set of issues when women are supported to engage in economic growth (Abney and González 2018). This kind of development encourages to support the economic empowerment of women and creates incentives to increase investment in female human capital - an investment that has returns not only for women but for men, children and nation as well. Gender equality leads to "smart Economics" (Buvinic \& King, 2007). This approach views gender equality as an integral part of economic development and aims to boost development through investing more efficiently in women and girls. Thus, investing in female human capital is resulting more effective development outcomes (Chant, 2012; Chant and Sweetman 2012). The need for development and facilitation of innovations dictate policy-makers to unlock cognitive potential of women and promote women economically to achieve better participation in decisionmaking and better positions at the top leadership level to influence company profitability at microeconomic level and welfare of population at the macroeconomic level (Sepashvili 2016, Sepashvili 2018a).

Women contribution to the economy is vital and proved by different studies and researches. The World Development
Report 2012 (World Bank, 2011) dedicated to Gender Equality and Development, confirmed the clear positive correlation between the women Economic Participation and the GDP level per capita and overall level of welfare. As world Economic Forum Report (2017) states, many empirical studies demonstrated that improved gender balance generates significant economic benefits, which differ according national characteristics of national economies, national cultural behavior and the challenges they are facing. Notable new estimates displays that economic gender equality could add an additional US\$250 billion to the GDP of the United Kingdom, US\$1,750 billion to the US, US\$550 billion to Japan GDPs, US\$320 billion to France GDP and US\$310 billion to German GDP. Other calculations suggest that China will have US\$2.5 trillion GDP increase if gender balance is realized and that the Global Economy could increase US\$5.3 trillion by 2025 if the gender gap is narrowed in economic participation by $25 \%$. More realistic calculation shows that, if female employment rates in OECD countries reaches the level Sweden experiences, GDP could be boost by over USD 6 trillion (PwC 2018).

The McKinsey Global Institute Report (2015) notes that $\$ 12$ trillion could be added to global GDP by 2025 by advancing women's equality within society by supporting public, private, and social sectors to act in coordination to close gender gaps. Scholars conducting the calculation note, that a "full-potential" scenario in which women participate in the economy is identical to that of men, would add up to $\$ 28$ trillion, or 26 percent, to annual global GDP in 2025 compared with a business-as-usual scenario. Of course reaching absolute parity is unrealistic, it is just noted the volume of the GDP that might be gained. Achieving even slightly better gender balance within society implies changes in cultural behavior, social attitudes, regulations and legislations. And visa-versa: changes in social norms and behavior in favor of women advancement leads to better women involvement in all spheres and especially in decision-making level. At the same time, it concerns personal choice of individuals, both men and women, how to allocate their time between un-paid and paid work, or how to participate in economics or politics.

Globally, Women comprise approximately the half the world's working-age population, but their contribution to the world GDP in only 37\%, the McKinsey Global Institute's Gender Parity Report 2015 says. This global average contribution to GDP covers large variations according the regions. The share of regional output generated by women is only $17 \%$ in India, $18 \%$ in the Middle East and North Africa (MENA), and $24 \%$ in South Asia (excluding India). In North America and Oceania, China, and Eastern Europe and Central Asia, the share is 40 to $41 \%$.

More women involvement leads to economic growth. International Monetary Fund (2018) research proves, that women economic empowerment supports productivity, increases inclusive economic growth and improves income equality alongside with other positive development outcomes. However, studies shows that growth does not inevitably lead 
to a reduction in gender inequality. On the contrary, it is assessed that gender gaps cost the economy some 15 percent of GDP (Cuberes and Teignier, 2016; Ferrant and Kolev, 2016). But just attracting women in labour force solve the problem only partially. Women participation at economic decisionmaking and women presence at top managerial positions is decisive to fully unlock economic potential and cognitive skills women hold.

Gender parity gives additional incentive to business development. Companies significantly benefit by giving possibility to women leadership that leads to increased effectiveness and growth (Sepashvili, 2019). It is assessed that companies with three or more women in senior managerial positions have higher score in all dimensions of performance (McKinsey \& Company, 2018). However, the reality is controversial: women face significant barriers, and often structural discrimination to hold highest leadership positions. According to Cheryl (Cheryl, 2014), only 5\% of Fortune 500 CEOs were women in 2014, and according new 2019 data women hold 24 (4.8\%) of CEO positions at those S\&P 500 companies. This vividly represents the real picture: while in recent years women experienced significant progress in career advancement, men are still majority on leadership positions such as high-level management, board of director seats, CEOs and est. Data from the most recent Global Entrepreneurship Monitor (GEM) suggest (Terjesen, 2012) that women represent one fourth of established business activity in countries and approximately one third of all new business activity around the globe.

\section{INTERNATIONAL RANKING OF COUNTRIES BY GENDER EQUALITY}

The sharpness and importance of barriers and obstacles impeding women promotion, vary by countries and relies on cultural and historical heritage, national mentality, government policy, gender role perception and so on. The difficulties facing women and girls over the globe are a major source of inequality. Women are discriminated against in health, education, political representation, labour market, etc. - with entails negative consequences for development. Despite this significant progress, that is evidenced by the World Bank Report on Development (World Bank, 2011), the situation in terms of gender equality still needs improvement, especially in its economic dimension. Encouraging trends are the higher number of women in the labour market and their progress in securing better education and training, as well as better access to health care and social protection.

The Global Gender Gap Report 2018 proves these significant achievements and notes the new threat of emerging gender misbalance in advanced technologies. In an era of fourth industrial revolution, when cognitive skills are increasingly vital to further technological development, no nation can afford to deprive women's human capital in the innovation development and knowledge generation, where attracting talent is crucial as this aspect of human capital is already scarce over the globe.

Since 2006 the Global Gender Gap Index measures the relative gaps between women and men across four key areas: health, education, economy and politics. Global Gender Gap Index measures gaps between male-female data rather than levels and quality. The Global Gender Gap Index points on the gaps between men and women according four main factors: 1. Economic Participation and Opportunity, 2.Educational Attainment, 3. Health and Survival and 4.Political Empowerment. It provides a comprehensive set of data and shows gaps on critical indicators, helping countries to set priorities within their own economic, political, social and cultural contexts. The Index also reveals those countries that-within their region or income group-are leaders in distributing resources more equitably between women and men, regardless of the overall level of available resources.

We will compare index for selected countries to track the tendency. Thus, for comparison we choose developed countries and countries, which are advanced in terms of gender equality. At the same time we will see the index for some former soviet countries and countries of soviet bloc in Eastern Europe. Soviet legislation had unprecedented high level of women promotion at all level, which was resulted in higher gender equality for former soviet countries, despite the fact that after the collapse of Soviet Union, all of them experienced deep economic crisis. And to completing the picture, some countries with the worst score are presented.

Data shows quite diverse picture according countries, but the tendency is that countries with high gender equality have good results in political empowerment and economic participation. However, direct and clear correlation is not observed as the history of achieving gender equality in these countries is different and greatly depends on social norms, cultural background and law enforcement. Worth to note that in former soviet countries gender equality is lower than the gender balance in economic opportunities. As it was already mentioned above, Soviet gender equality policy helped number of countries to reach better equality in economic terms. The most distinguished example is Belarus, which ranks as $\mathbf{2 8}$ for total score and is 6th in terms of economic participation and opportunity. The same picture is observed for other countries as well. The Global index rank and subindex rank for economic participation significantly differs for Russian Federation, Ukraine, and Kazakhstan: global index ranks are 75, 65 and 60 accordingly for these countries, while sub-index indicating economic opportunities shows a better picture and ranks are 31, 28 and 32, accordingly. Azerbaijan, Armenia and Georgia are considerably lagging back in terms of gender equality: their ranking are as follow: 97, 98 and 99 accordingly. Azerbaijan gained the highest ranking - 47 in terms of economic equality among these countries, while Armenia 
Table 1. Global Gender Gap Index 2018. Rank of selected countries

\begin{tabular}{|c|c|c|c|c|c|c|}
\hline$\#$ & Country & Global Index & $\begin{array}{l}\text { Economic participation } \\
\text { and opportunity }\end{array}$ & $\begin{array}{l}\text { Educational } \\
\text { attainment }\end{array}$ & $\begin{array}{l}\text { Health and } \\
\text { survival }\end{array}$ & $\begin{array}{l}\text { Political } \\
\text { empowerment }\end{array}$ \\
\hline 1 & Iceland & 1 & 16 & 39 & 121 & 1 \\
\hline 2 & Norway & 2 & 11 & 41 & 95 & 3 \\
\hline 3 & Sweden & 3 & 9 & 52 & 115 & 7 \\
\hline 4 & Finland & 4 & 17 & 1 & 60 & 6 \\
\hline 5 & Slovenia & 11 & 15 & 29 & 1 & 22 \\
\hline 6 & France & 12 & 63 & 1 & 78 & 10 \\
\hline 7 & Denmark & 13 & 38 & 1 & 100 & 15 \\
\hline 8 & Canada & 16 & 27 & 1 & 104 & 21 \\
\hline 9 & Latvia & 17 & 10 & 1 & 1 & 42 \\
\hline 10 & Bulgaria & 18 & 50 & 27 & 42 & 45 \\
\hline 11 & Lithuania & 24 & 21 & 53 & 1 & 41 \\
\hline 12 & Belarus & 28 & 6 & 49 & 52 & 74 \\
\hline 13 & Estonia & 33 & 42 & 1 & 42 & 51 \\
\hline 14 & Moldova & 35 & 18 & 69 & 1 & 72 \\
\hline 15 & United States & 51 & 19 & 46 & 71 & 98 \\
\hline 16 & Kazakhstan & 60 & 32 & 30 & 42 & 94 \\
\hline 17 & Ukraine & 65 & 28 & 26 & 56 & 105 \\
\hline 18 & Russian Federation & 75 & 31 & 28 & 1 & 123 \\
\hline 19 & Kyrgyz Republic & 86 & 78 & 79 & 1 & 93 \\
\hline 20 & Azerbaijan & 97 & 47 & 33 & 146 & 137 \\
\hline 21 & Armenia & 98 & 73 & 35 & 148 & 115 \\
\hline 22 & Georgia & 99 & 85 & 60 & 123 & 119 \\
\hline 23 & Iraq & 147 & 149 & 136 & 76 & 90 \\
\hline 24 & Pakistan & 148 & 146 & 139 & 145 & 97 \\
\hline 25 & Yemen & 148 & 147 & 146 & 126 & 149 \\
\hline
\end{tabular}

Source: Global Gender Gap Report (2018), World Economic Forum, 2018

ranks 73 and the worst result in economic sub-index- 85, was confirmed for Georgia. As for other developed countries, like Iceland, Norway, Sweden and Finland, being the best countries in terms of general gender equality, their results in economic sub-index shows worse ranking - 16, 11, 9 and 17 accordingly, but still demonstrating excellent results in comparison with former soviet countries.

Another source estimating gender equality is Human Development Report, which measures Gender Inequality Index (GII) taking into account three main factors of human development. 1. Women reproductive health measured by maternal mortality ratio and adolescent birth rates; 2 . Women empowerment measured by women participation in parliament and women access to education and 3. Economic status estimated by women participation in labour force.

The GIl measures the human development costs of gender inequality. Thus, GII highlights the inequalities between females and males and notes damage to human development in this regard. The Gll gives new picture of the position of women in 160 countries and points on gender gaps in major areas of human development. The component indicators emphasize areas in need of critical political intervention and offers solid food for thoughts. It assists public policy to correctly choose systematic disadvantages of women urgently need to be overcome.

Gender equality index for the same countries are as following: Table 2.

Data on gender equality index for same countries show slightly different picture and ranks, though the clear tendency is that countries with higher index of human development experience higher level of gender equality. However, some countries demonstrate better results in terms of human development (Iceland 6, Norway -1, Canada - 12, United States -13 ,) while their results in gender inequality index in worse (Iceland 9, Norway -5 Canada - 20, United States -41). For majority of countries the gender inequality index is higher in comparison with human development index. Azerbaijan, Armenia and Georgia showed better ranks for gender inequality index, 71, 55 and 78 accordingly, while human development level for these countries is worse: 80, 90 and 70 accordingly.

McKinsey Global Institute's Gender Parity report 2015, assess 15 gender equality indicators for 95 countries. The indicators fall into four categories: equality in work, essential services and enablers of economic opportunity, legal protection and political voice and physical security and autonomy. The scores is set at 1.00 as the ideal gender parity and countries 
Table 2. Gender Inequality Index 2017

\begin{tabular}{|c|c|c|c|c|c|}
\hline & country & $\begin{array}{c}\text { Human } \\
\text { Development index } \\
\text { rank }\end{array}$ & $\begin{array}{l}\text { Gender Inequality } \\
\text { Index rank }\end{array}$ & $\begin{array}{l}\text { Share of seats in } \\
\text { parliament } \\
\text { (\% held by women) }\end{array}$ & $\begin{array}{l}\text { Skilled labour Force } \\
\text { (\% of labor force) } \\
\text { (2011-2017) }\end{array}$ \\
\hline 1 & Iceland & 6 & 9 & 38,1 & 73,4 \\
\hline 2 & Norway & 1 & 5 & 41,4 & 82,4 \\
\hline 3 & Sweden & 7 & 3 & 43,6 & 84,9 \\
\hline 4 & Finland & 15 & 8 & 42,0 & 88,3 \\
\hline 5 & Slovenia & 25 & 7 & 28,7 & 90,6 \\
\hline 6 & France & 24 & 16 & 35,5 & 82,6 \\
\hline 7 & Denmark & 11 & 2 & 37,4 & 76,6 \\
\hline 8 & Canada & 12 & 20 & 30,1 & 90,0 \\
\hline 9 & Latvia & 41 & 42 & 16,0 & 91,2 \\
\hline 10 & Bulgaria & 51 & 46 & 23,8 & 87,6 \\
\hline 11 & Lithuania & 35 & 28 & 21,3 & 95,7 \\
\hline 12 & Belarus & 53 & 31 & 33,1 & 98,6 \\
\hline 13 & Estonia & 30 & 27 & 26,7 & 89,2 \\
\hline 14 & Moldova & 112 & 48 & 22,8 & 60,7 \\
\hline 15 & United States & 13 & 41 & 19,7 & 83,2 \\
\hline 16 & Kazakhstan & 58 & 43 & 22,1 & 75,1 \\
\hline 17 & Ukraine & 88 & 61 & 12,2 & 98,1 \\
\hline 18 & Russian Federation & 49 & 53 & 16,1 & 96,1 \\
\hline 19 & Kyrgyz Republic & 122 & 91 & 19,2 & 92,1 \\
\hline 20 & Azerbaijan & 80 & 71 & 16,8 & 93,0 \\
\hline 21 & Armenia & 83 & 55 & 18,1 & 94,4 \\
\hline 22 & Georgia & 70 & 78 & 16,0 & 94,4 \\
\hline 23 & Iraq & 120 & 123 & 25,3 & 28,4 \\
\hline 24 & Pakistan & 150 & 153 & 20,0 & 28,3 \\
\hline 25 & Yemen & 178 & 160 & 0,5 & 30,9 \\
\hline
\end{tabular}

Source: Human Development Report 2018, United Nations Development Program, http://hdr.undp.org/en/composite/GII

and regions are assessed by their distance each country has to reach absolute gender parity. This index clearly shows a strong link between gender equality in society, beliefs, social norms, cultural behavior and attitudes about the role of women, and gender equality in work. The report concludes that gender equality in work is not achievable without the gender equality in society and social norms. Researchers fail to find a country with high gender equality in society but low gender equality in work. The report concludes that economic development supports countries to narrow gender gaps, but progress in four areas in particular-education level, financial and digital inclusion, legal protection, and unpaid care work-could help to accelerate progress.

McKinsey Global Institute's Gender Parity Report 2015 data indicates the lowest scores 0.44 for South Asia (excluding India), North America and Oceania gained the highest score at 0,74. The Eastern Europe and Central Asia, where former soviet and Eastern European former socialist countries are

\begin{tabular}{|l|l|}
\hline & Very high human development \\
\hline & High human development \\
\hline & Medium human development \\
\hline & Low human development \\
\hline
\end{tabular}

concentered, gained 0.67, a little bit higher as of 0.71 score was given to Western Europe region, where major advanced European countries are located. As for remainder part of the world, the scores were as following for the regions: 0,64 Latin America; 0,62 East and South East Asia, 0,57 Sub-Saharan Africa and 0,48 Middle East and North Africa.

The women high representation was observed in unpaid work, which was accompanied by their lowest involvement in paid work. Globally, $75 \%$ of the world's total unpaid care is carried out by women, such as family care, child and elderly care, cooking, and cleaning. However, this contribution is not calculated in traditional measures of GDP. Report estimates 
Table 3. Women in Business

\begin{tabular}{|c|c|c|c|c|}
\hline & $\begin{array}{l}\text { Percent of firms with } \\
\text { female participation in } \\
\text { ownership }\end{array}$ & $\begin{array}{c}\text { Percent of firms } \\
\text { with majority female } \\
\text { ownership }\end{array}$ & $\begin{array}{c}\text { Percent of firms with a } \\
\text { female top manager }\end{array}$ & $\begin{array}{l}\text { Proportion of permanent } \\
\text { full-time workers that are } \\
\text { female }(\%)\end{array}$ \\
\hline All Countries & 33.6 & 14.6 & 18 & 30.6 \\
\hline East Asia \& Pacific & 46.9 & 28 & 32.6 & 37.6 \\
\hline Europe \& Central Asia & 32.5 & 12.6 & 18.9 & 37.8 \\
\hline Latin America \& Caribbean & 49.9 & 19.9 & 20.1 & 33.8 \\
\hline Middle East \& North Africa & 23.3 & 3.4 & 5.4 & 17.6 \\
\hline South Asia & 18.4 & 9.6 & 11 & 18.3 \\
\hline Sub-Saharan Africa & 29.2 & 13.4 & 15.8 & 26.5 \\
\hline Armenia (2013) & 25.3 & 14.5 & 19.1 & 46.4 \\
\hline Azerbaijan (2013) & 4.5 & 2 & 2.4 & 31.3 \\
\hline Belarus (2013) & 43.6 & 18.6 & 32.7 & 50.9 \\
\hline Bulgaria (2013) & 39 & 12.4 & 23.9 & 41.3 \\
\hline Georgia (2013) & 33.9 & 19.2 & 44.4 & 44 \\
\hline $\operatorname{Iraq}(2011)$ & 6.8 & n.a. & 2.3 & 8.6 \\
\hline Kazakhstan (2013) & 28.3 & 16.4 & 18.9 & 35.5 \\
\hline Kyrgyz Republic (2013) & 49.4 & 16.4 & 28.8 & 46 \\
\hline Latvia (2013) & 36.3 & 22.8 & 31.5 & 44.4 \\
\hline Lithuania (2013) & 35.8 & 16.5 & 21 & 38.4 \\
\hline Moldova (2013) & 47.3 & 28.5 & 25.7 & 42 \\
\hline Pakistan (2013) & 11.8 & 8 & 6 & 7.3 \\
\hline Russian Federation (2012) & 28.5 & n.a. & 20.1 & 43.4 \\
\hline Slovenia (2013) & 34.5 & 13.3 & 18.8 & 33.6 \\
\hline Sweden (2014) & 52.5 & 9.3 & 12.5 & 34.5 \\
\hline Ukraine (2013) & 31.5 & 12.9 & 18.8 & 41.4 \\
\hline Uzbekistan (2013) & 29.2 & 7.9 & 13.4 & 27 \\
\hline
\end{tabular}

Source: Enterprise Surveys 2019, The World Bank, http://www.enterprisesurveys.org

that unpaid work being undertaken by women as much as $\$ 10$ trillion of output per year, approximately equivalent to $13 \%$ of global GDP.

Interesting picture reveals to study women participation in firm ownership, management, and the workforce. The World Bank Enterprise Surveys 2019 give some interesting data on these indicators and provides useful information about women economic participation in the labor force and their entrepreneurship activities.

As data show in the table, women participation in firm ownership is high in countries that experience good level of human development or presented good balance of gender equality. Sweden, Russian, Moldova, Kyrgyz republic, Latvia, Lithuania, Georgia, Ukraine, Slovenia, Belarus, Bulgaria have more than $30 \%$ of women in firm ownership, and just some of them (Belarus, Georgia, Latvia) have more than $30 \%$ women in top management.

As data of different Institutions showed there are no clear correlation of gender equality with some specific factor, though countries with high level of human development an economic development showed better results in terms of gender equality. Despite the varied measuring methodology, the factors affecting gender equality are approximately the same and concern gender balance in decision-making, economic opportunities, access to health care and social protection, education. At the same time, gender equality has clear social character and implies cultural and historical aspects of the countries' development.

\section{CONCLUSION}

Thus, there is no doubt that gender balance in economic terms boost countries' development and hence, welfare. The gender equality means equal opportunities and rights for both men and women in political, economic and social spheres. This kind of approach advocates gender equality and balanced involvement of men and women at macro level and at micro level. These are the areas that policy makers have to address to create national competitive model to increase resource efficiency. Therefore, achieving greater gender equality is becoming one of the most significant factors for modern economic policy which should encourage the factors, features and elements positively contributing country's welfare. The important message to be considered is that gender equality leads to smarts economics and creates sound base for resource efficiency and innovative development which is crucial for reaching higher competitiveness in global markets. 


\section{REFERENCES:}

1. Abney David and González Laya Arancha (2018), This Is Why Women Must Play a Greater Role in the Global Economy, World Economic Forum, January, 2018. Retrieved https://www.weforum.org/agenda/2018/01/this-is-why-women-must-play-a-greaterrole-in-the-global-economy/

2. Chant, S. (2012). «The disappearing of (smart economics»? The World Development Report 2012 on Gender Equality: Some concerns about the preparatory process and the prospects for paradigm change». Global Social Policy. 12 (2): $198-218$.

3. Chant, Sylvia; Sweetman, Caroline (2012). «Fixing women or fixing the world? (Smart economics», efficiency approaches, and gender equality in development». Gender \& Development. 20 (3): 517-529..

4. Cheryl. (2014). Women CEOs of the S\&P 500. http://www.catalyst.org/knowledge/women-ceos-sp-500

5. Cuberes, D., \& Teignier, M. (2016). Aggregate Effects of Gender Gaps in the Labor Market: A Quantitative Estimate. Journal of Human Capital, 10(1), 1-32.https://doi.org/10.1086/683847

6. Ferrant, G. and A. Kolev (2016), Does gender discrimination in social institutions matter for long-term growth?: Cross-country evidence. OECD Development Centre Working Papers, No. 330, OECD Publishing, Paris, https://doi.org/10.1787/5jm2hz8dgls6-en

7. Gazzola Patrizia, Sepashvili Eka, Pezzetti Roberta, (2016) Corporate Social Responsibility as a Mean To Promote Gender Equality. Business and Management Sciences International Quarterly Review, Pavia, Giugno 2016, Vol.7 Retrieved from http://riviste. paviauniversitypress.it/index.php/ea/article/viewFile/1788/1859

8. Gazzola Patrizia, Sepashvili Eka, Roberta Pezzetti (2018) How Sustainable Enterprises Can Drive The Sustainable Development, European Scientific Journal February 2018 /SPECIAL/ edition. p 26-36.

9. Global Gender Gap Report (2018), World Economic Forum, 2018, retrieved from: http://www3.weforum.org/docs/WEF_ GGGR_2018.pdf

10. Human Development Report 2018, United Nations Development Program, retrieved from: http://hdr.undp.org/en/composite/GI 11. International Monetary Fund (2018). Pursuing Womenıs Economic Empowerment https://www.imf.org/en/Publications/PolicyPapers/Issues/2018/05/31/pp053118pursuing-womens-economic-empowerment

12. McKinsey \& Company (2018), Women Matter: Time to accelerate. Ten years of insights into gender diversity 2018. Retrieved from: $\quad$ https://www.empowerwomen.org/-/media/files/un\%20women/empowerwomen/resources/hlp\%20briefs/unhlp\%20 full\%20report.pdf?la=en ..[7]

13. PwC, Women in Work Index 2018. Available at: https://www.pwc.co.uk/services/economics-policy/insights/women-in-workindex.html

14. Schwab Klaus (2017) The Fourth Industrial Revolution, World Economic Forum, 2017 retrieved from: https://www.weforum.org/ about/the-fourth-industrial-revolution-by-klaus-schwab

15. Sepashvili Eka (2019) Gender Dimension of Economic Decision-Making: Women on Top Management, Business and Management Sciences International Quarterly Review, Pavia, Giugno 2019, Vol. Retrieved from

16. Sepashvili Eka (2018)a. Innovative Clusters - A Model for Rising International Competitiveness. 5th Business Systems Laboratory International Symposium «Co-creating Responsible Futures in the Digital Age: Exploring new paths towards economic, social and environmental Sustainability». January, 2018; p.2019-22;

17. Sepashvili Eka (2018)b. Innovations and Global Economy. International Scientific-Practical Magazine, Globalization and Business \#5/2018. p. 158-163

18. Sepashvili Eka, (2016). Globalized World Economy, Innovations and National Policies for Economic Growth. Business Systems Laboratory 4th International Symposium, 'Governing Business Systems. Theories and Challenges for Systems. Thinking in Practice. Vilnius, August, 2016, pp. 174-76. Retrieved from: http://bslab-symposium.net/Vilnius.2016/BSLab-Vilnius2016-e-book_of_ Abstracts.pdf

19. Sustainable Development Goals, UN, retrieved from: https://sustainabledevelopment.un.org/?menu=1300;

20. Terjesen Siri, 2012, Women entrepreneurship: A force for growth, Trade forum ASPX, retrieved from: https://www. researchgate.net/profile/Amanda_Elam/publication/285764926_Women_entrepreneurship_A_force_for_growth/ links/56bb7cfc08ae2481ab6ac2c2/Women-entrepreneurship-A-force-for-growth.pdf

21. The Power of Parity: How Advancing Women's Equality Can Add \$12 trillion to Global Growth. (2015), McKinsey Global Institute, September, 2015, retrieved from: https://www.mckinsey.com/ /media/McKinsey/Featured\%20Insights/Employment\%20and\%20 Growth/How\%20advancing\%20womens\%20equality\%20can\%20add\%2012\%20trillion\%20to\%20global\%20growth/MGI\%20 Power\%20of\%20parity_Executive\%20summary_September\%202015.ashx;

22. World Bank (2012). 2012 Development Report. Retrieved from: https://openknowledge.worldbank.org/handle/10986/4391

23. World Bank (2012). Development Report 2012. Retrieved from https://openknowledge.worldbank.org/handle/10986/4391

24. World Economic Forum (2017), Global Gender Gap 2017, retrieved from: http://reports.weforum.org/global-gender-gapreport-2017/results-and-analysis 


\section{WOMEN FOR GLOBAL GROWTH: NEED FOR WOMEN ECONOMIC EMPOWERMENT}

\section{EKA SEPASHVILI}

Doctor of Economics

Associate Professor

Ivane Javakhishvili Tbilisi State University, Georgia

Eka.sepashvili@gmail.com

KEYWORDS: GENDER EQUALITY, WOMEN ECONOMIC EMPOWERMENT, GLOBAL GROWTH.

For citation: Sepashvili E. (2019), Women For Global Growth: Need For Women Economic Empowerment, Globalization And Business, №7, pp. 96-103. https://doi.org/10.35945/gb.2019.07.012

\section{SUMMARY}

Modern global economic development heavily relies on new technologies and unprecedented development of science creating more and more new innovative products and services. In such reality the demand for knowledge generation and improvement of resource efficiency is critical. More than ever, nations cannot afford to lose the skills, ideas and perspectives of women who are currently under-represented - in order to utilize the promise of a more prosperous and human-centric future that is to be come soon by contemporary innovations and technologies.

New challenges for national economic policies generate new approaches which have to face these modern developments and trends. One of the efficient practices represents women promotion for a very simple reason: women yet are not fully engaged into development and their economic potential has to be unlocked to benefit not only economic goals but also social inclusion and human development to meet upmost goal of every state: inclusive growth and high level of welfare. In this regard, women promotion and their empowerment are key policy challenges. Nowadays the need for women advancement in all spheres of the society is clear and generates no doubts for reasonability and rationality of such approach to economic growth.

Women contribution to the economy is vital and proved by different studies and researches. As data of different Institutions showed, there are no clear correlations of gender equality with some specific factors, though countries with high level of human development and economic development showed better results in terms of gender equality. The important message to be considered is that gender equality leads to smarts economics and creates sound base for resource efficiency and innovative development which is crucial for reaching higher competitiveness in global markets. 